\title{
Biological compatibility between two temperate lineages of brown dog ticks, Rhipicephalus sanguineus (sensu lato)
}

Filipe Dantas-Torres ${ }^{1,2^{*}}$ (D) Maria Stefania Latrofa ${ }^{2}$, Rafael Antonio Nascimento Ramos ${ }^{3}$, Riccardo Paolo Lia ${ }^{2}$, Gioia Capelli ${ }^{4}$, Antonio Parisi ${ }^{5}$, Daniele Porretta ${ }^{6}$, Sandra Urbanelli ${ }^{6}$ and Domenico Otranto ${ }^{2^{*}}$

\begin{abstract}
Background: The brown dog tick Rhipicephalus sanguineus (sensu stricto) is reputed to be the most widespread tick of domestic dogs worldwide and has also been implicated in the transmission of many pathogens to dogs and humans. For more than two centuries, Rh. sanguineus (s.s.) was regarded as a single taxon, even considering its poor original description and the inexistence of a type specimen. However, genetic and crossbreeding experiments have indicated the existence of at least two distinct taxa within this name: the so-called "temperate" and "tropical" lineages of Rh. sanguineus (sensu lato). Recent genetic studies have also demonstrated the existence of additional lineages of Rh. sanguineus (s.l.) in Europe and Asia. Herein, we assessed the biological compatibility between two lineages of Rh. sanguineus (s.l.) found in southern Europe, namely Rhipicephalus sp. I (from Italy) and Rhipicephalus sp. II (from Portugal).
\end{abstract}

Methods: Ticks morphologically identified as Rh. sanguineus (s.l.) were collected in southern Portugal and southern Italy. Tick colonies were established and crossbreeding experiments conducted. Morphological, biological and genetic analyses were conducted.

Results: Crossbreeding experiments confirmed that ticks from the two studied lineages were able to mate and generate fertile hybrids. Hybrid adult ticks always presented the same genotype of the mother, confirming maternal inheritance of mtDNA. However, larvae and nymphs originated from Rhipicephalus sp. I females presented mtDNA genotype of either Rhipicephalus sp. I or Rhipicephalus sp. II, suggesting the occurrence of paternal inheritance or mitochondrial heteroplasmy. While biologically compatible, these lineages are distinct genetically and phenotypically.

Conclusions: The temperate lineages of $R$ h. sanguineus (s.l.) studied herein are biologically compatible and genetic data obtained from both pure and hybrid lines indicate the occurrence of paternal inheritance or mitochondrial heteroplasmy. This study opens new research avenues and raises question regarding the usefulness of genetic data and crossbreeding experiments as criteria for the definition of cryptic species in ticks.

Keywords: Ticks, Genetics, Morphology, Biology, Crossbreeding, Paternal inheritance, Mitochondrial heteroplasmy

\footnotetext{
*Correspondence: filipe.dantas@cpqam.fiocruz.br; domenico.otranto@uniba.it

'Department of Immunology, Aggeu Magalhães Institute, Oswaldo Cruz

Foundation (Fiocruz), Recife, Pernambuco 50670420, Brazil

${ }^{2}$ Department of Veterinary Medicine, University of Bari, 70010 Valenzano, Bari,

Italy

Full list of author information is available at the end of the article
}

(c) The Author(s). 2018 Open Access This article is distributed under the terms of the Creative Commons Attribution 4.0 International License (http://creativecommons.org/licenses/by/4.0/), which permits unrestricted use, distribution, and reproduction in any medium, provided you give appropriate credit to the original author(s) and the source, provide a link to the Creative Commons license, and indicate if changes were made. The Creative Commons Public Domain Dedication waiver (http://creativecommons.org/publicdomain/zero/1.0/) applies to the data made available in this article, unless otherwise stated. 


\section{Background}

Ticks are external parasites of great medical and veterinary significance, causing incalculable losses to the livestock industry and a great burden on companion animals and human populations around the world [1, 2]. Climate changes, deforestation, biodiversity loss, animal and human population movements, changes in land-use, political and economic crises, among other factors, have induced changes in the distribution and epidemiological pattern of tick-borne diseases in various parts of the world [3].

Taxonomy and systematics of ticks have traditionally been based on morphological features. In the last three decades, the widespread use of genetic data and phylogenetic analysis has revolutionized both taxonomy and systematics of the Ixodida [4], but generated many questions as well about the specific identity of certain taxa $[5,6]$. A classic example is what happened with the Rhipicephalus sanguineus group, which is an assembly of 17 morphologically similar tick species, including $R h$. sanguineus (sensu stricto) [5, 6]. For over 200 years, $R h$. sanguineus (s.s.) was believed to be a single taxon, even considering its poor original description and the inexistence of a type-specimen [5, 6]. However, it has been proposed that, until a neotype of $R$ h. sanguineus (s.s.) is designated, ticks assigned to this taxon should be referred to as Rh. sanguineus (sensu lato) [5, 6]. Indeed, genetic and crossbreeding experiments have indicated the existence of at least two distinct taxa within this name: the "temperate" and "tropical" lineages of Rh. sanguineus (s.l.) [7-18]. Additional genetic lineages have been identified in Europe and Asia, such as the lineage originally designated as "Rhipicephalus sp. I", which is present in some temperate countries, such as Italy and Greece [13]. The presence of this lineage has also recently been confirmed in eastern European countries (e.g. Romania and Serbia) and in the Middle East (e.g. Israel) [19]. The existence of different lineages or cryptic species within Rh. sanguineus (s.l.) has implications, not only from a taxonomic perspective but also from a medico-veterinary standpoint. Indeed, ticks currently identified as $R h$. sanguineus (s.l.) are vectors of various bacteria (e.g. Rickettsia rickettsii, $R$. conorii and Ehrlichia canis), protozoans (e.g. Babesia vogeli and Hepatozoon canis) causing diseases in dogs and/or humans $[1,5]$. For instance, evidence indicates that the vector competence of the temperate and tropical lineages of Rh. sanguineus (s.l.) for E. canis may vary [20].

In Europe, at least two genetic lineages of Rh. sanguineus (s.l.) are known to occur: the so-called temperate lineage (also referred to as "Rhipicephalus sp. II", a terminology that will be used herein for clarity's sake, as we are dealing with two different temperate lineages) and Rhipicephalus sp. I [13, 19]. However, little is known about the current distribution (including areas of sympatry) of ticks belonging to these lineages and it is unknown whether they can breed and produce fertile hybrids in nature. Indeed, so far, only in Algeria and in southern Italy (Sicily insular region) ticks of both lineages have been retrieved [21]. The possible occurrence of incomplete reproductive isolation between the two lineages has been recently hypothesized based on the polymorphisms observed at the calreticulin gene (crt gene) [22]. In fact, ticks genetically assigned to Rhipicephalus sp. I and Rhipicephalus sp. II shared crt intron-present and intron-absent alleles and one Rhipicephalus sp. I individual from Putignano (Bari, southern Italy) showed both alleles, which could support the occurrence of a heterozygous genotype and ongoing gene flow. Alternatively, incomplete lineage sorting or past gene flow could explain the observed pattern at the crt gene locus. Within this context, the main objectives of this study were: (i) to characterize morphologically and molecularly the pure Rhipicephalus sp. I and Rhipicephalus sp. II tick lines; (ii) to verify the biological compatibility between ticks from these two lineages by performing crossbreeding experiments; and (iii) to assess the fertility of pure and hybrid tick lines.

\section{Methods}

\section{Tick lines}

Ticks used in this study originated from Portugal and Italy. In particular, engorged females genetically identified (see section "Genetic study") as Rhipicephalus sp. I and Rhipicephalus sp. II were originally collected from sheltered dogs in Putignano (Bari, southern Italy) and privately-owned dogs living in Faro (southern Portugal), respectively. In the above-mentioned collection sites, only these genotypes have been found in previous studies $[13,19,23]$.

Larvae (and subsequent nymphal and adult stages) originated from wild-caught, engorged females were defined as "wild type". Ticks generated from males and females belonging to the same lineage were defined as "pure tick lines", whereas ticks obtained by crossing different lineages were defined as "hybrid tick lines". The first and second laboratory generations of crossed tick lines were designated as $F_{1}$ and $F_{2}$, respectively.

Throughout the study, all ticks were maintained in a laboratory incubator under controlled conditions of temperature, relative humidity and light, and fed on naïve rabbits, as described elsewhere [24].

\section{Morphological study}

Unfed larvae and nymphs (10-20 days of age) from pure progenies were killed with warm water $\left(50{ }^{\circ} \mathrm{C}\right)$ and placed in vials containing $70 \%$ ethanol. Then, they were mounted on glass slides using Hoyer's solution [25] and 
examined under a light microscope. Newly emerged unfed adults from pure progenies were placed in vials containing $70 \%$ ethanol and examined directly under a stereomicroscope. All specimens were photographed and measurements taken using Leica Application Suite version 4.1 software (Leica Microsystems, Wetzlar, Germany). The following structures were measured: idiosoma length and width; scutum length and width; capitulum length; basis capituli length and width; hypostome length and palpal length; adanal plate length and width; adanal plate length/width ratio; dorsal prolongation of spiracular plate width; first festoon width; and the ratio between the width of the dorsal prolongation of spiracular plate and the width of the adjacent festoon (DPSP/AF ratio). The lengths of paired dorsal setae for larvae (scutal 3, central dorsal 1 and 2) and nymphs (central scutal 1 to 4 ) were also measured. Measurements are expressed as mean \pm standard deviation and are provided in micrometres for larvae and in millimetres for nymphs and adults.

\section{Crossbreeding experiments}

Crossbreeding experiments were carried out and the fertility of hybrid tick lines was assessed until the second generation $\left(F_{2}\right)$ (Table 1). The following parameters were analysed: female feeding period (days); female feeding success (\%); engorgement weight (g); pre-oviposition period (days); oviposition period (days); engorged females laying eggs (\%); egg-mass weight (g); blood meal conversion index (\%); egg incubation period (days); egg hatchability (\%); larval moulting success (\%); nymphal moulting success (\%); and sex ratio (female:male). The above parameters were also recorded for pure tick lines under the same conditions, being calculated as reported elsewhere [24].

\section{Genetic study}

Wild type ticks belonging to the lineages Rhipicephalus sp. I and Rhipicephalus sp. II, as well as larvae, nymphs, males and females from laboratory pure and hybrid tick lines (G1, G2, G3 and G4), were used for genetic analysis. Genomic DNA was extracted from individual specimens using a commercial kit (DNeasy Blood \& Tissue Kit, Qiagen $\mathrm{GmbH}$, Hilden, Germany), following the manufacturer's instructions. Partial cytochrome $c$ oxidase subunit 1 ( $\operatorname{cox} 1)$ gene sequences ( $472 \mathrm{bp}$ ) were amplified using primers and PCR conditions described elsewhere [26]. Each reaction consisted of $4 \mu \mathrm{l}$ of tick genomic DNA and $46 \mu \mathrm{l}$ of PCR mix containing $2.5 \mathrm{mM} \mathrm{MgCl}, 10 \mathrm{mM}$ Tris- $\mathrm{HCl}(\mathrm{pH} 8.3)$, and $50 \mathrm{mM} \mathrm{KCl}, 250 \mu \mathrm{M}$ of each dNTP, 50 pmol of each primer and 1.25 $\mathrm{U}$ of AmpliTaq Gold (Applied Biosystems, Foster City, CA, USA). Approximately 100 ng of genomic DNA (with the exception of the no-template control) were added to each PCR. Amplified products were examined on $2 \%$ agarose gels stained with GelRed (VWR International PBI, Milan, Italy) and visualized on a GelLogic 100 gel documentation system (Kodak, New York, USA). Amplicons were purified and sequenced, in both directions using the same primers as for PCR, employing the Big Dye Terminator v.3.1 chemistry in an automated sequencer (3130 Genetic Analyzer, Applied Biosystems, Foster City, CA, USA). The cox 1 gene sequences were aligned using the ClustalW program [27] and compared with those available in GenBank using the BLASTn tool (http://blast.ncbi.nlm.nih.gov/Blast.cgi).

\section{Statistical analysis}

The mean differences of measurements were compared between $F_{1}$ ticks (larvae, nymphs, males and females) of Rhipicephalus sp. I and Rhipicephalus sp. II, by analysis of variance (ANOVA). Morphometric data generated was also analysed through discriminant analysis to classify $F_{1}$ ticks into different groups, based on a series of correlated variables (measurements). A structure matrix was generated for $F_{1}$ larvae, nymphs, and adults (females and males) to highlight those variables that have the strongest correlations with the canonical function and that could help to discriminate between group 1 (G1) and group 2 (G2) (pure tick lines). The canonical function was then used to predict group membership and the success of assignment into the right group was expressed in percentage of correct classification. Statistical analysis was performed using SPSS for Windows, version 13.0.

\section{Results \\ Morphometric study}

Morphometric data obtained from $F_{1}$ ticks belonging to G1 and G2 are provided in Tables 2, 3, 4, 5. Some

Table 1 Tick groups used in this study

\begin{tabular}{lll}
\hline Group & Tick line & Specimens used \\
\hline G1 & Pure line of Rhipicephalus sp. II & 10 females and 10 males from Portugal \\
G3 & Pure line of Rhipicephalus sp. I & 10 females and 10 males from Italy \\
G4 & Crossed line with females of Rhipicephalus sp. II & 10 females from Portugal and 10 males from Italy \\
\hline
\end{tabular}

Adult ticks used to establish both pure and crossed lines belonged to the wild type; they were obtained from nymphs that moulted from larvae obtained from wild-caught, engorged females. $F_{1}$ and $F_{2}$ generations from crossed lines are referred to as hybrids 
Table 2 Measurements (in $\mu \mathrm{m}$ ) of and comparisons between $F_{1}$ larvae from pure tick lines

\begin{tabular}{|c|c|c|c|c|c|}
\hline Measurement & Group & Mean \pm SD & Range & $F$ & $P$ \\
\hline \multirow[t]{2}{*}{ Idiosoma length } & G1 & $577 \pm 21$ & $561-614$ & \multirow[t]{2}{*}{$F_{(1,18)}=1.134$} & \multirow[t]{2}{*}{0.301} \\
\hline & $\mathrm{G} 2$ & $588 \pm 22$ & $552-620$ & & \\
\hline \multirow[t]{2}{*}{ Idiosoma width } & G1 & $396 \pm 13$ & $377-409$ & \multirow[t]{2}{*}{$F_{(1,18)}=17.255$} & \multirow[t]{2}{*}{0.001} \\
\hline & $\mathrm{G} 2$ & $420 \pm 13$ & $402-441$ & & \\
\hline \multirow[t]{2}{*}{ Scutum length } & G1 & $207 \pm 10$ & $193-221$ & \multirow[t]{2}{*}{$F_{(1,18)}=7.816$} & \multirow[t]{2}{*}{0.012} \\
\hline & $\mathrm{G} 2$ & $218 \pm 6$ & $208-230$ & & \\
\hline \multirow[t]{2}{*}{ Scutum width } & G1 & $324 \pm 10$ & 309-338 & \multirow[t]{2}{*}{$F_{(1,18)}=8.634$} & \multirow[t]{2}{*}{0.009} \\
\hline & $\mathrm{G} 2$ & $336 \pm 8$ & $326-353$ & & \\
\hline \multirow[t]{2}{*}{ Dorsal setae length } & G1 & $23 \pm 1$ & $22-25$ & \multirow[t]{2}{*}{$F_{(1,18)}=21.094$} & \multirow[t]{2}{*}{0.0001} \\
\hline & G2 & $21 \pm 1$ & $19-23$ & & \\
\hline \multirow[t]{2}{*}{ Capitulum length } & G1 & $107 \pm 10$ & $97-129$ & \multirow[t]{2}{*}{$F_{(1,18)}=5.076$} & \multirow[t]{2}{*}{0.037} \\
\hline & G2 & $116 \pm 8$ & $98-123$ & & \\
\hline \multirow[t]{2}{*}{ Basis capituli length } & G1 & $52 \pm 4$ & $46-59$ & \multirow[t]{2}{*}{$F_{(1,18)}=0.020$} & \multirow[t]{2}{*}{0.890} \\
\hline & G2 & $52 \pm 4$ & $44-57$ & & \\
\hline \multirow[t]{2}{*}{ Basis capituli width } & G1 & $143 \pm 6$ & $133-154$ & \multirow[t]{2}{*}{$F_{(1,18)}=9.322$} & \multirow[t]{2}{*}{0.007} \\
\hline & $\mathrm{G} 2$ & $150 \pm 2$ & $147-152$ & & \\
\hline \multirow[t]{2}{*}{ Hypostome length } & G1 & $55 \pm 7$ & $48-70$ & \multirow[t]{2}{*}{$F_{(1,18)}=9.732$} & \multirow[t]{2}{*}{0.006} \\
\hline & $\mathrm{G} 2$ & $64 \pm 5$ & $54-71$ & & \\
\hline \multirow[t]{2}{*}{ Palpal length } & G1 & $79 \pm 4$ & $73-86$ & \multirow[t]{2}{*}{$F_{(1,18)}=4.037$} & \multirow[t]{2}{*}{0.060} \\
\hline & $\mathrm{G} 2$ & $82 \pm 3$ & $75-86$ & & \\
\hline
\end{tabular}

Statistically significant differences from ANOVA tests are indicated in bold

Table 3 Measurements (in $\mathrm{mm}$ ) of and comparisons between $\mathrm{F}_{1}$ nymphs from pure tick lines

\begin{tabular}{|c|c|c|c|c|c|}
\hline Measurements & Groups & Mean \pm SD & Range & $F$ & $P$ \\
\hline \multirow[t]{2}{*}{ Idiosoma length } & G1 & $1.40 \pm 0.02$ & $1.38-1.42$ & \multirow[t]{2}{*}{$F_{(1,18)}=34.165$} & \multirow[t]{2}{*}{$<0.00001$} \\
\hline & G2 & $1.34 \pm 0.02$ & $1.30-1.36$ & & \\
\hline \multirow[t]{2}{*}{ Idiosoma width } & G1 & $0.79 \pm 0.02$ & $0.76-0.83$ & \multirow[t]{2}{*}{$F_{(1,18)}=148.45$} & \multirow[t]{2}{*}{$<0.00001$} \\
\hline & G2 & $0.66 \pm 0.03$ & $0.64-0.71$ & & \\
\hline \multirow[t]{2}{*}{ Scutum length } & G1 & $0.53 \pm 0.01$ & $0.52-0.56$ & \multirow[t]{2}{*}{$F_{(1,18)}=11.650$} & \multirow[t]{2}{*}{0.003} \\
\hline & G2 & $0.52 \pm 0.01$ & $0.51-0.53$ & & \\
\hline \multirow[t]{2}{*}{ Scutum width } & G1 & $0.60 \pm 0.01$ & $0.59-0.62$ & \multirow[t]{2}{*}{$F_{(1,18)}=59.163$} & \multirow[t]{2}{*}{$<0.00001$} \\
\hline & $\mathrm{G} 2$ & $0.57 \pm 0.01$ & $0.54-0.58$ & & \\
\hline \multirow[t]{2}{*}{ Dorsal setae length } & G1 & $0.26 \pm 0.002$ & $0.23-0.29$ & \multirow[t]{2}{*}{$F_{(1,18)}=29.215$} & \multirow[t]{2}{*}{$<0.00001$} \\
\hline & $\mathrm{G} 2$ & $0.21 \pm 0.002$ & $0.19-0.24$ & & \\
\hline \multirow[t]{2}{*}{ Capitulum length } & G1 & $0.23 \pm 0.01$ & $0.22-0.25$ & \multirow[t]{2}{*}{$F_{(1,18)}=3.315$} & \multirow[t]{2}{*}{0.085} \\
\hline & G2 & $0.22 \pm 0.01$ & $0.21-0.24$ & & \\
\hline \multirow[t]{2}{*}{ Basis capituli length } & G1 & $0.12 \pm 0.004$ & $0.12-0.13$ & \multirow[t]{2}{*}{$F_{(1,18)}=4.765$} & \multirow[t]{2}{*}{0.043} \\
\hline & $\mathrm{G} 2$ & $0.12 \pm 0.01$ & $0.10-0.13$ & & \\
\hline \multirow[t]{2}{*}{ Basis capituli width } & G1 & $0.34 \pm 0.01$ & $0.32-0.35$ & \multirow[t]{2}{*}{$F_{(1,18)}=0.019$} & \multirow[t]{2}{*}{0.893} \\
\hline & $\mathrm{G} 2$ & $0.34 \pm 0.01$ & $0.32-0.34$ & & \\
\hline \multirow[t]{2}{*}{ Hypostome length } & G1 & $0.11 \pm 0.01$ & $0.99-0.12$ & \multirow[t]{2}{*}{$F_{(1,18)}=0.023$} & \multirow[t]{2}{*}{0.880} \\
\hline & $\mathrm{G} 2$ & $0.11 \pm 0.01$ & $0.98-0.13$ & & \\
\hline \multirow[t]{2}{*}{ Palpal length } & G1 & $0.16 \pm 0.01$ & $0.14-0.17$ & \multirow[t]{2}{*}{$F_{(1,18)}=0.139$} & \multirow[t]{2}{*}{0.713} \\
\hline & G2 & $0.16 \pm 0.01$ & $0.14-0.18$ & & \\
\hline
\end{tabular}


Table 4 Measurements (in $\mathrm{mm}$ ) of and comparisons between $F_{1}$ males from pure tick lines

\begin{tabular}{|c|c|c|c|c|c|}
\hline Measurements & Groups & Mean \pm SD & Range & $F$ & $P$ \\
\hline \multirow[t]{2}{*}{ Idiosoma length } & G1 & $3.33 \pm 0.16$ & $3.10-3.53$ & $F_{(1,18)}=7.039$ & 0.016 \\
\hline & G2 & $3.52 \pm 0.17$ & $3.23-3.75$ & & \\
\hline \multirow[t]{2}{*}{ Idiosoma width } & G1 & $1.72 \pm 0.09$ & $1.60-1.90$ & $F_{(1,18)}=7.039$ & $<0.00001$ \\
\hline & $\mathrm{G} 2$ & $1.92 \pm 0.10$ & $1.80-2.10$ & & \\
\hline \multirow[t]{2}{*}{ Scutum length } & G1 & $2.87 \pm 0.11$ & $2.73-3.02$ & $F_{(1,18)}=2.572$ & 0.126 \\
\hline & $\mathrm{G} 2$ & $2.96 \pm 0.15$ & $2.73-3.13$ & & \\
\hline \multirow[t]{2}{*}{ Scutum width } & G1 & $1.55 \pm 0.07$ & $1.41-1.65$ & $F_{(1,18)}=10.198$ & 0.005 \\
\hline & G2 & $1.70 \pm 0.13$ & $1.55-2.02$ & & \\
\hline \multirow[t]{2}{*}{ Capitulum length } & G1 & $0.50 \pm 0.06$ & $0.37-0.58$ & $F_{(1,18)}=11.066$ & 0.004 \\
\hline & G2 & $0.57 \pm 0.04$ & $0.52-0.61$ & & \\
\hline \multirow[t]{2}{*}{ Basis capituli length } & G1 & $0.27 \pm 0.03$ & $0.20-0.30$ & $F_{(1,18)}=7.000$ & 0.016 \\
\hline & G2 & $0.30 \pm 0.02$ & $0.30-0.30$ & & \\
\hline \multirow[t]{2}{*}{ Basis capituli width } & G1 & $0.72 \pm 0.03$ & $0.68-0.76$ & $F_{(1,18)}=10.245$ & 0.045 \\
\hline & G2 & $0.77 \pm 0.04$ & $0.70-0.82$ & & \\
\hline \multirow[t]{2}{*}{ Hypostome length } & G1 & $0.23 \pm 0.06$ & $0.08-0.28$ & $F_{(1,18)}=4.607$ & 0.046 \\
\hline & G2 & $0.27 \pm 0.03$ & $0.22-0.32$ & & \\
\hline \multirow[t]{2}{*}{ Palpal length } & G1 & $0.31 \pm 0.02$ & $0.28-0.35$ & $F_{(1,18)}=0.352$ & 0.560 \\
\hline & $\mathrm{G} 2$ & $0.31 \pm 0.02$ & $0.28-0.35$ & & \\
\hline \multirow[t]{2}{*}{ Adanal plate length } & G1 & $0.89 \pm 0.07$ & $0.79-1.00$ & $F_{(1,18)}=0.472$ & 0.501 \\
\hline & G2 & $0.92 \pm 0.07$ & $0.83-0.99$ & & \\
\hline \multirow[t]{2}{*}{ Adanal plate width } & G1 & $0.36 \pm 0.04$ & $0.30-0.43$ & $F_{(1,18)}=4.863$ & 0.041 \\
\hline & G2 & $0.39 \pm 0.02$ & $0.36-0.42$ & & \\
\hline \multirow[t]{2}{*}{ Adanal plate length/width ratio } & G1 & $2.51 \pm 0.11$ & $2.28-2.70$ & $F_{(1,18)}=8.920$ & 0.008 \\
\hline & G2 & $2.36 \pm 0.11$ & $2.20-2.61$ & & \\
\hline \multirow[t]{2}{*}{ Dorsal prolongation of spiracular plate width } & G1 & $0.07 \pm 0.01$ & $0.06-0.08$ & $F_{(1,18)}=1.521$ & 0.233 \\
\hline & G2 & $0.07 \pm 0.01$ & $0.06-0.09$ & & \\
\hline \multirow[t]{2}{*}{ First festoon width } & G1 & $0.13 \pm 0.02$ & $0.10-0.15$ & $F_{(1,18)}=21.550$ & $<0.00001$ \\
\hline & G2 & $0.16 \pm 0.01$ & $0.14-0.17$ & & \\
\hline \multirow[t]{2}{*}{ DPSP/AF ratio ${ }^{a}$} & G1 & $0.51 \pm 0.08$ & $0.45-0.63$ & $F_{(1,18)}=4.865$ & 0.041 \\
\hline & G2 & $0.45 \pm 0.04$ & $0.41-0.53$ & & \\
\hline
\end{tabular}

The ratio between the width dorsal prolongation of spiracular plate and the width of the adjacent festoon

Statistically significant differences from ANOVA tests are indicated in bold

variables showed cases of overlapping measurements, while others did not. Overall, the means of several measurements (7/10 for larvae, 6/10 for nymphs, 11/ 15 for males, 2/12 for females) were significantly different between G1 and G2 (Tables 2, 3, 4, 5). The discriminant analysis confirmed idiosoma width as the most discriminant variable to distinguish nymphs from G1 and G2, followed by scutum width and idiosoma length (Table 6). The discriminating power of the variables for larvae, males and females was lower than for nymphs (Table 6). Nonetheless, using discriminant analysis, 100\% of the larvae and nymphs were correctly assigned to the original lineage (Table 7 ).

\section{Crossbreeding experiments}

Crossbreeding experiments showed that Rhipicephalus sp. I males were able to mate with Rhipicephalus sp. II females, and vice versa, generating fertile hybrids. Detailed data from biological parameters recorded for pure and hybrid tick lines (G3 and G4) are provided in Table 8. Engorged $F_{1}$ and $F_{2}$ females from all groups showed similar patterns in terms of feeding success, engorgement weight, pre-oviposition period, oviposition period, egg-mass weight produced and blood meal conversion index. However, with regard to hybrids, engorged $F_{2}$ females were heavier than those of $F_{1}$, although they did not produce greater egg masses. Indeed, 
Table 5 Measurements (in $\mathrm{mm}$ ) of and comparisons between $\mathrm{F}_{1}$ females from pure tick lines

\begin{tabular}{|c|c|c|c|c|c|}
\hline Measurements & Groups & Mean \pm SD & Range & $F$ & $P$ \\
\hline \multirow[t]{2}{*}{ Idiosoma length } & G1 & $3.27 \pm 0.18$ & $3.00-3.54$ & $F_{(1,18)}=0.022$ & 0.885 \\
\hline & $\mathrm{G} 2$ & $3.26 \pm 0.14$ & $2.92-3.42$ & & \\
\hline \multirow[t]{2}{*}{ Idiosoma width } & G1 & $1.56 \pm 0.08$ & $1.50-1.70$ & $F_{(1,18)}=1.694$ & 0.210 \\
\hline & G2 & $1.60 \pm 0.07$ & $1.50-1.70$ & & \\
\hline \multirow[t]{2}{*}{ Scutum length } & G1 & $1.57 \pm 0.07$ & $1.44-1.64$ & $F_{(1,18)}=7.704$ & 0.012 \\
\hline & $\mathrm{G} 2$ & $1.63 \pm 0.04$ & $1.58-1.70$ & & \\
\hline \multirow[t]{2}{*}{ Scutum width } & G1 & $1.37 \pm 0.08$ & $1.27-1.51$ & $F_{(1,18)}=1.662$ & 0.214 \\
\hline & $\mathrm{G} 2$ & $1.41 \pm 0.04$ & $1.37-1.48$ & & \\
\hline \multirow[t]{2}{*}{ Capitulum length } & G1 & $0.62 \pm 0.04$ & $0.57-0.67$ & $F_{(1,18)}=0.890$ & 0.358 \\
\hline & $\mathrm{G} 2$ & $0.64 \pm 0.04$ & $0.58-0.69$ & & \\
\hline \multirow[t]{2}{*}{ Basis capituli length } & G1 & $0.30 \pm 0.03$ & $0.30-0.40$ & $F_{(1,18)}=0.859$ & 0.366 \\
\hline & G2 & $0.30 \pm 0.01$ & $0.30-0.30$ & & \\
\hline \multirow[t]{2}{*}{ Basis capituli width } & G1 & $0.82 \pm 0.02$ & $0.78-0.84$ & $F_{(1,18)}=5.468$ & 0.031 \\
\hline & G2 & $0.84 \pm 0.02$ & $0.79-0.86$ & & \\
\hline \multirow[t]{2}{*}{ Hypostome length } & G1 & $0.32 \pm 0.02$ & $0.29-0.36$ & $F_{(1,18)}=3.115$ & 0.095 \\
\hline & $\mathrm{G} 2$ & $0.34 \pm 0.04$ & $0.28-0.39$ & & \\
\hline \multirow[t]{2}{*}{ Palpal length } & G1 & $0.38 \pm 0.02$ & $0.35-0.40$ & $F_{(1,18)}=0.692$ & 0.416 \\
\hline & $\mathrm{G} 2$ & $0.37 \pm 0.01$ & $0.35-0.38$ & & \\
\hline \multirow[t]{2}{*}{ Dorsal prolongation of spiracular plate width } & G1 & $0.07 \pm 0.01$ & $0.06-0.08$ & $F_{(1,18)}=0.367$ & 0.552 \\
\hline & G2 & $0.07 \pm 0.01$ & $0.06-0.08$ & & \\
\hline \multirow[t]{2}{*}{ First festoon width } & G1 & $0.18 \pm 0.02$ & $0.15-0.21$ & $F_{(1,18)}=1.429$ & 0.247 \\
\hline & G2 & $0.17 \pm 0.01$ & $0.15-0.18$ & & \\
\hline
\end{tabular}

Statistically significant differences from ANOVA tests are indicated in bold

they presented lower blood meal conversion index as compared with $\mathrm{F}_{1}$ females. The minimum egg incubation period and egg hatchability were also similar across generations (Table 8). No noticeable differences were found in relation to larval and nymphs moulting rates, with the exception of the lowest moulting rates recorded for $F_{2}$ larvae $(80 \%)$ and nymphs (95.3\%) from the hybrid line with females of Rhipicephalus sp. I (Table 8). No parthenogenesis was observed in any of the groups; the proportion of males in $F_{1}$ ranged between $45-50 \%$, with sex ratios (females:males) close to unity in all groups (1:1 in G1, G2 and G4, and 1:0.8 in G3).

Genetic identification and mitochondrial DNA inheritance In total, 122 partial cox 1 sequences were generated and analysed [Additional files 1 and 2]. Sequences obtained from "wild-type" ticks shared 99-100\% nucleotide identity with sequences for reference strains of Rhipicephalus sp. I (GenBank: KC243884, KC243883) or Rhipicephalus sp. II (GenBank: KC243891) retrieved from GenBank, confirming the genetic identity of the ticks used in this study. No ambiguous single nucleotide polymorphisms were detected for the sequence obtained from G1 and G2 offspring specimens.
All immature and adult $F_{1}$ ticks from pure and hybrid lines showed the maternal mtDNA as expected, with the exception of larvae and nymphs originating from Rhipicephalus sp. I females, which showed either the Rhipicephalus sp. I or Rhipicephalus sp. II genotype. A high percentage of nucleotide identity (99-100\%) was recorded by comparing all $F_{1}$ tick sequences with the reference strains, for each group and developmental stage examined.

\section{Discussion}

In the present study, we conducted morphometric, biological and genetic comparisons between two temperate lineages of Rh. sanguineus (s.l.), namely Rhipicephalus sp. I and Rhipicephalus sp. II. Phenotypically, these lineages are very similar, but morphometric analysis revealed differences for some measurements, especially for larvae and nymphs (Table 6). In fact, all larvae and nymphs were correctly classified by discriminant analysis (Table 7). Scutal and alloscutal setae, along with idiosoma width, scutum width and length were among the best discriminating variables for larvae and nymphs of Rhipicephalus sp. I and Rhipicephalus sp. II. As a matter of fact, some of these characters (e.g. scutal and alloscutal setae) had already 
Table 6 Pooled within-groups correlations between pure lines ticks (G1 and G2), discriminating variables and standardized canonical discriminant functions

\begin{tabular}{|c|c|c|c|c|}
\hline \multirow[t]{2}{*}{ Variable } & \multicolumn{4}{|c|}{ Absolute size of correlation within function } \\
\hline & Larvae & Nymphs & Females & Males \\
\hline Dorsal setae length & -0.413 & 0.276 & - & - \\
\hline Idiosoma width & 0.374 & 0.622 & 0.165 & 0.314 \\
\hline Hypostome length & 0.281 & 0.008 & 0.224 & 0.137 \\
\hline Basis capituli width & 0.275 & -0.007 & 0.296 & 0.204 \\
\hline Scutum width & 0.264 & 0.393 & 0.163 & 0.204 \\
\hline Scutum length & 0.251 & 0.174 & 0.352 & 0.102 \\
\hline Capitulum length & 0.203 & 0.093 & 0.120 & 0.212 \\
\hline Palpal length & 0.181 & 0.019 & -0.105 & 0.038 \\
\hline Idiosoma length & 0.096 & 0.298 & -0.019 & 0.169 \\
\hline Basis capituli length & 0.013 & 0.111 & -0.117 & 0.169 \\
\hline DPSP/AF ratio ${ }^{a}$ & - & - & 0.179 & -0.141 \\
\hline First festoon width & - & - & -0.151 & 0.296 \\
\hline Dorsal prolongation of spiracular plate width & - & - & 0.077 & 0.079 \\
\hline Adanal plate length & - & - & - & 0.044 \\
\hline Adanal plate width & - & - & - & 0.141 \\
\hline Adanal plate length/width ratio & - & - & - & -0.206 \\
\hline
\end{tabular}

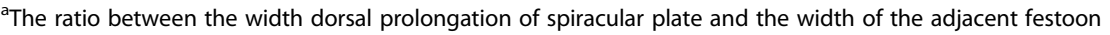

Bold indicates the higher correlation within function for each tick developmental stage

been suggested as reliable morphological characters for separating Rh. sanguineus (s.l.) and R. turanicus [28]. Altogether, our results indicate that the combined analysis of several measurements is the most reliable way to separate morphologically larvae and nymphs of these lineages.

Previous studies using ticks belonging to the tropical and temperate lineages of Rh. sanguineus (s.l.) revealed that these ticks could mate and generate viable hybrids $[11,29]$. Most of the eggs produced by hybrid females obtained in these studies were infertile, but some larvae successfully hatched in at least one study [29]. This indicates that the tropical and temperate lineages of $R h$. sanguineus (s.l.) have been separated for quite some time; this hypothesis is also supported by the differences found in their mitochondrial genomes [14]. A recent laboratory study suggested that their geographical isolation may have been driven by climatic factors [30].

Table 7 Classification of $F_{1}$ tick specimens as belonging to $G 1$ or G2 based on discriminant analysis

\begin{tabular}{|c|c|c|c|c|c|c|c|c|}
\hline \multirow[t]{3}{*}{ Group of origin } & \multicolumn{8}{|c|}{ Predicted group membership } \\
\hline & \multicolumn{2}{|c|}{ Larvae } & \multicolumn{2}{|c|}{ Nymphs } & \multicolumn{2}{|c|}{ Females } & \multicolumn{2}{|c|}{ Males } \\
\hline & G1 & G2 & G1 & G2 & G1 & $\mathrm{G} 2$ & G1 & $\mathrm{G} 2$ \\
\hline G1 & 10 & 0 & 10 & 0 & 7 & 3 & 9 & 1 \\
\hline G2 & 0 & 10 & 0 & 10 & 3 & 7 & 2 & 8 \\
\hline Correctly classified (\%) & 100 & & 100 & & 70 & & 85 & \\
\hline
\end{tabular}

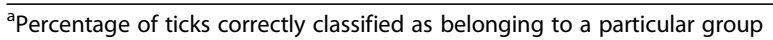

Our experiments confirmed that Rhipicephalus sp. I males were able to mate with Rhipicephalus sp. II females, and vice versa, generating fertile hybrids. While this may suggest that these lineages are conspecific, previous studies have shown hybridization to be possible in some tick species, under both laboratory [31, 32] and natural conditions [33]. Therefore, the ability to mate and generate fertile descendants cannot be used as a sole criterion to assess conspecificity.

It is worth nothing that, while morphologically similar and biologically compatible, Rhipicephalus sp. I and Rhipicephalus sp. II are genetically quite divergent, i.e. up to $7,10.4$ and $12.5 \%$ for $16 S$ rRNA, $12 S$ rRNA and cox1 genes, respectively [13]. To put this into perspective, the pairwise distances (for cox 1 sequences) between Rhipicephalus sp. I and Rh. guilhoni, Rh. pusillus, Rh. turanicus, and tropical lineage of Rh. sanguineus (s.l.) were $10 \%, 11.1 \%, 11.7 \%$ and $12.3 \%$, respectively [13]. These findings raise interesting questions regarding the biological and genetic species concepts in ticks belonging to the genus Rhipicephalus. The ability of ticks from different species to mate and generate fertile hybrids has been previously demonstrated in the laboratory, for instance, with Rh. appendiculatus and Rh. zambeziensis [34]. Altogether, these data suggest that the results of crossbreeding experiments and phylogenetic analysis may not be concordant and therefore should be 
Table 8 Biological parameters recorded for different tick lines ${ }^{a}$ used in this study

\begin{tabular}{|c|c|c|c|c|c|c|c|c|}
\hline \multirow[t]{2}{*}{ Parameters } & \multicolumn{2}{|l|}{ Pure lines } & \multicolumn{2}{|c|}{ Crossed lines } & \multicolumn{2}{|c|}{ Hybrid lines $\left(F_{1}\right)$} & \multicolumn{2}{|c|}{ Hybrid lines $\left(F_{2}\right)$} \\
\hline & G1 & G2 & G3 & G4 & G3 & G4 & G3 & G4 \\
\hline Female feeding period (days) & $18.5 \pm 1.4$ & $21.4 \pm 1.2$ & $14.6 \pm 2.3$ & $18.0 \pm 0.0$ & $16.0 \pm 0.0$ & $13.3 \pm 2.00$ & $12.0 \pm 0.0$ & $11.0 \pm 0.0$ \\
\hline Female feeding success (\%) & 40.0 & 55.0 & 30.0 & 50.0 & 50.0 & 60.0 & 60.0 & 40.0 \\
\hline Engorgement weight (g) & $0.2 \pm 45.6$ & $0.3 \pm 45.4$ & $0.3 \pm 15.4$ & $0.3 \pm 45.8$ & $0.3 \pm 46.4$ & $0.3 \pm 88.1$ & $0.3 \pm 0.02$ & $0.4 \pm 0.0$ \\
\hline Pre-oviposition period (days) & $3.3 \pm 0.7$ & $3.0 \pm 1.0$ & $2.1 \pm 1.5$ & $2.2 \pm 1.3$ & $3.4 \pm 1.2$ & $3.0 \pm 0.6$ & $1.0 \pm 0.0$ & $1.0 \pm 0.0$ \\
\hline Oviposition period (days) & $13.3 \pm 1.0$ & $14.2 \pm 1.9$ & $16.6 \pm 2.0$ & $15.4 \pm 1.5$ & $14.2 \pm 2.6$ & $17.3 \pm 2.3$ & $14.2 \pm 2.9$ & $11.3 \pm 0.5$ \\
\hline Engorged females laying eggs (\%) & 100.0 & 100.0 & 100.0 & 100.0 & 100.0 & 100.0 & 100.0 & 87.5 \\
\hline Egg-mass weight (g) & $0.1 \pm 33.5$ & $0.2 \pm 29.4$ & $0.2 \pm 15.2$ & $0.2 \pm 40.5$ & $0.2 \pm 0.1$ & $0.2 \pm 0.1$ & $0.2 \pm 30.3$ & $0.2 \pm 21.0$ \\
\hline Blood meal conversion index (\%) & 57.4 & 66.2 & 67.1 & 68.4 & 73.4 & 78.2 & 59.0 & 66.9 \\
\hline Egg incubation period (days) & $5.5 \pm 0.5$ & $6.4 \pm 0.9$ & $5.5 \pm 0.5$ & $7.9 \pm 1.1$ & $9.2 \pm 2.2$ & $12.3 \pm 2.3$ & $10.5 \pm 1.1$ & $12.5 \pm 1.8$ \\
\hline Egg hatchability (\%) & 100.0 & 100.0 & 95.5 & 99.4 & 86.0 & 93.0 & 100.0 & 98.0 \\
\hline Larval moulting success (\%) & 99.6 & 98.8 & 98.6 & 98.7 & 99.5 & 99.5 & 95.0 & 80.0 \\
\hline Nymphal moulting success (\%) & 100.0 & 100.0 & 100.0 & 100.0 & 96.3 & 99.5 & 98.2 & 95.3 \\
\hline
\end{tabular}

${ }^{a}$ Crossed lines refer to pure females from a given lineage that mated with pure males from a different lineage. Larvae and nymphs from these crosses are hybrids generated from these crosses. Hybrid lines refer to hybrid males and females (and their offspring), obtained from crossed tick lines

carefully interpreted while assessing the conspecificity or distinctiveness of closely related species belonging to this genus.

Other researchers have recognized that Rhipicephalus sp. I and Rhipicephalus sp. II are different evolutionary entities $[19,35]$. Indeed, recent studies indicated that the distribution of these two temperate lineages is disrupted, with Rhipicephalus sp. I being found in Africa (north of the Sahara) and south-eastern Europe, and Rhipicephalus sp. II being predominantly found from the middle to the western part of Europe [19, 23, 35]. Interestingly, both lineages have been found in Italy, with Rhipicephalus sp. I reported in the south (Puglia and Sicily) and Rhipicephalus sp. II in both the south (Sicily) and the north (Verona) [13, 21]. This suggests that these lineages may occur in sympatry in southern Italy, but probably in a limited geographical area. However, their actual distribution ranges across the country and the possible areas of sympatry remain to be investigated. In the same way, the driving factors for their genetic differentiation and apparent incomplete reproductive isolation are unknown. Factors such as temporal (e.g. seasonal shift) and spatial isolation (e.g. habitat preference) may not be enough to explain these differences as both lineages studied herein display similar seasonal patterns and are predominately parasitic on dogs [23, 36, 37].

The occurrence of hybrids in sympatric zones as well as their impact (if any) in the occurrence of certain pathogens should be investigated. For instance, a study evaluated the vector capacity of ticks from four populations (i.e. two from Brazil, one from Argentina and one from Uruguay) of Rh. sanguineus (s.l.) for transmitting E. canis [20]. The study showed that only ticks from a population from south-eastern Brazil (belonging to the tropical lineage) were able to transmitting the bacterium to naïve dogs. Further research is needed to assess the vectorial competence of Rhipicephalus sp. I and Rhipicephalus sp. II for human pathogens, including the bacterium $R$. conorii, the main causative agent of Mediterranean spotted fever.

Both the pure line of Rhipicephalus sp. II and the cross between Rhipicephalus sp. II females and Rhipicephalus sp. I males generated larvae, nymphs and adults presenting the same mtDNA genotype of their female progenitor. On the other hand, the cross between Rhipicephalus sp. I females and Rhipicephalus sp. II males generated larvae and nymphs presenting either Rhipicephalus sp. I or Rhipicephalus sp. II mtDNA genotypes. This suggests the occurrence of paternal leakage (i.e. transmission of mitochondrial DNA from father to offspring) or mitochondrial heteroplasmy of parental females (i.e. presence of multiple mitochondrial genotypes within an individual). This hypothesis opens up new research avenues concerning mitochondrial inheritance and heteroplasmy in ticks and should be investigated in future studies.

Interestingly, adult ticks from all groups presented mtDNA of their mothers. The finding of paternal mtDNA in larvae and nymphs and the absence in adults descending from Rhipicephalus sp. I females may suggest that the persistence of paternal mtDNA or heteroplasmy may vary across tick developmental stages. For instance, it has been shown that heteroplasmy frequency changes between tissues of the same individual and between generations in humans [38]. It is also worth mentioning that the detection of heteroplasmy by DNA sequencing is challenging if one of the haplotypes occurs at low frequency [39]. These hypotheses should be investigated in future large-scale studies with natural populations of these tick lineages. 


\section{Conclusions}

The temperate lineages of $R h$. sanguineus (s.l.) studied herein are biologically compatible and genetic data obtained from both pure and hybrid lines suggest the occurrence of paternal inheritance or mitochondrial heteroplasmy. This study opens new research avenues and raises question regarding the usefulness of genetic data and crossbreeding experiments as criteria for the definition of cryptic species in ticks.

\section{Additional files}

Additional file 1: Table S1. Group, stage, generation and genotype of ticks genetically identified in this study. (DOCX $18 \mathrm{~kb}$ )

Additional file 2: Partial cytochrome c oxidase subunit 1 (cox1) gene sequences generated in this study. (FAS $60 \mathrm{~kb}$ )

\section{Abbreviations}

cox1 gene: Cytochrome c oxidase subunit 1 gene; crt gene: Calreticulin gene; mtDNA: Mitochondrial DNA; Rh.: Rhipicephalus; s.l.: sensu lato; s.s.: sensu stricto

\section{Acknowledgements}

The authors thank Dr Viviana Domenica Tarallo for her support in laboratory and field activities.

\section{Funding}

This study was partly supported by funding from Bayer Animal Health.

\section{Availability of data and materials}

All relevant data are included within the article and its additional files.

\section{Authors' contributions}

Study concept: FDT and DO. Data collection: FDT, RPL, RANR, MSL and AP. Data analysis: FDT, MSL, GC, DP, SU and DO. Manuscript writing: FDT. All authors read and approved the final manuscript.

\section{Ethics approval and consent to participate}

All animal experiments were conducted in strict accordance with principles of the 105 3Rs European directive (2010/63/EU), National Animal Testing Rules (D.Lgs 116/92) and all efforts were made to minimize animal suffering. All procedures were approved by the University of Bari, Bari, Italy (protocol no. 9/12).

\section{Consent for publication}

Not applicable.

\section{Competing interests}

The authors declare that they have no competing interests.

\section{Publisher's Note}

Springer Nature remains neutral with regard to jurisdictional claims in published maps and institutional affiliations.

\section{Author details}

${ }^{1}$ Department of Immunology, Aggeu Magalhães Institute, Oswaldo Cruz Foundation (Fiocruz), Recife, Pernambuco 50670420, Brazil. ²Department of Veterinary Medicine, University of Bari, 70010 Valenzano, Bari, Italy. ${ }^{3}$ Academic Unit of Garanhuns, Federal Rural University of Pernambuco, Garanhuns, Pernambuco 55292270, Brazil. ${ }^{4}$ Istituto Zooprofilattico Sperimentale delle Venezie, 35020 Legnaro, Italy. ${ }^{5}$ Istituto Zooprofilattico Sperimentale della Puglia e della Basilicata, Contrada S. Pietro Piturno, 70017 Putignano, Bari, Italy. ${ }^{6}$ Department of Environmental Biology, Sapienza University of Rome, 00185 Rome, Italy.
Received: 4 February 2018 Accepted: 7 June 2018

Published online: 09 July 2018

\section{References}

1. Dantas-Torres F, Chomel BB, Otranto D. Ticks and tick-borne diseases: a One Health perspective. Trends Parasitol. 2012;28:437-46.

2. Estrada-Peña A. Ticks as vectors: taxonomy, biology and ecology. Rev Sc Tech. 2015;34:53-65.

3. Dantas-Torres F. Climate change, biodiversity, ticks and tick-borne diseases: the butterfly effect. Int J Parasitol Parasites Wildl. 2015;4:452-61.

4. Nava S, Guglielmone AA, Mangold AJ. An overview of systematics and evolution of ticks. Front Biosci (Landmark Ed). 2009;(14):2857-77.

5. Dantas-Torres F, Otranto D. Further thoughts on the taxonomy and vector role of Rhipicephalus sanguineus group ticks. Vet Parasitol. 2015;208:9-13.

6. Nava S, Estrada-Peña A, Petney T, Beati L, Labruna MB, Szabó MP, et al. The taxonomic status of Rhipicephalus sanguineus (Latreille, 1806). Vet Parasitol. 2015;208:2-8.

7. Oliveira PR, Bechara GH, Denardi SE, Saito KC, Nunes ET, Szabó MP, et al. Comparison of the external morphology of Rhipicephalus sanguineus (Latreille, 1806) (Acari: Ixodidae) ticks from Brazil and Argentina. Vet Parasitol. 2005;129:139-47.

8. Szabó MP, Mangold AJ, João CF, Bechara GH, Guglielmone AA. Biological and DNA evidence of two dissimilar populations of the Rhipicephalus sanguineus tick group (Acari: Ixodidae) in South America. Vet Parasitol. 2005: 130:131-40

9. Burlini L, Teixeira KR, Szabó MP, Famadas KM. Molecular dissimilarities of Rhipicephalus sanguineus (Acari: Ixodidae) in Brazil and its relation with samples throughout the world: is there a geographical pattern? Exp Appl Acarol. 2010;50:361-74.

10. Moraes-Filho J, Marcili A, Nieri-Bastos FA, Richtzenhain LJ, Labruna MB. Genetic analysis of ticks belonging to the Rhipicephalus sanguineus group in Latin America. Acta Trop. 2011;117:51-5.

11. Levin ML, Studer E, Killmaster L, Zemtsova G, Mumcuoglu KY. Crossbreeding between different geographical populations of the brown dog tick, Rhipicephalus sanguineus (Acari: Ixodidae). Exp Appl Acarol. 2012;58:51-68.

12. Nava S, Mastropaolo M, Venzal JM, Mangold AJ, Guglielmone AA. Mitochondrial DNA analysis of Rhipicephalus sanguineus sensu lato (Acari: Ixodidae) in the Southern Cone of South America. Vet Parasitol. 2012:190:547-55.

13. Dantas-Torres F, Latrofa MS, Annoscia G, Giannelli A, Parisi A, Otranto D. Morphological and genetic diversity of Rhipicephalus sanguineus sensu lato from the New and Old Worlds. Parasit Vectors. 2013;6:213.

14. Liu GH, Chen F, Chen YZ, Song HQ, Lin RQ, Zhou DH, et al. Complete mitochondrial genome sequence data provides genetic evidence that the brown dog tick Rhipicephalus sanguineus (Acari: Ixodidae) represents a species complex. Int J Biol Sci. 2013;9:361-9.

15. Hekimoğlu O, Sağlam IK, Özer N, Estrada-Peña A. New molecular data shed light on the global phylogeny and species limits of the Rhipicephalus sanguineus complex. Ticks Tick Borne Dis. 2016;7:798-807.

16. Sanches GS, Évora PM, Mangold AJ, Jittapalapong S, Rodriguez-Mallon A, Guzmán PE, et al. Molecular, biological, and morphometric comparisons between different geographical populations of Rhipicephalus sanguineus sensu lato (Acari: Ixodidae). Vet Parasitol. 2016;215:78-87.

17. Zemtsova GE, Apanaskevich DA, Reeves WK, Hahn M, Snellgrove A, Levin ML. Phylogeography of Rhipicephalus sanguineus sensu lato and its relationships with climatic factors. Exp Appl Acarol. 2016:69:191-203.

18. Caetano RL, Vizzoni VF, Bitencourth K, Carriço C, Sato TP, Pinto ZT, et al. Ultrastructural morphology and molecular analyses of tropical and temperate "species" of Rhipicephalus sanguineus sensu lato (Acari: Ixodidae) in Brazil. J Med Entomol. 2017:54:1201-12.

19. Hornok S, Sándor AD, Tomanović S, Beck R, D'Amico G, Kontschán J, et al. East and west separation of Rhipicephalus sanguineus mitochondrial lineages in the Mediterranean Basin. Parasit Vectors. 2017:10:39.

20. Moraes-Filho J, Krawczak FS, Costa FB, Soares JF, Labruna MB. Comparative evaluation of the vector competence of four South American populations of the Rhipicephalus sanguineus group for the bacterium Ehrlichia canis, the agent of canine monocytic ehrlichiosis. PLoS One. 2015;10:e0139386.

21. Latrofa MS, Dantas-Torres F, Giannelli A, Otranto D. Molecular detection of tick-borne pathogens in Rhipicephalus sanguineus group ticks. Ticks Tick Borne Dis. 2014;5:943-6. 
22. Porretta D, Latrofa MS, Dantas-Torres F, Mastrantonio V, latta R, Otranto $D$, et al. Exon-intron structure and sequence variation of the calreticulin gene among Rhipicephalus sanguineus group ticks. Parasit Vectors. 2016:9:640.

23. Dantas-Torres F, Maia C, Latrofa MS, Annoscia G, Cardoso L, Otranto D. Genetic characterization of Rhipicephalus sanguineus (sensu lato) ticks from dogs in Portugal. Parasit Vectors. 2017;10:133.

24. Dantas-Torres F, Figueredo LA, Otranto D. Seasonal variation in the effect of climate on the biology of Rhipicephalus sanguineus in southern Europe. Parasitology. 2011;138:527-36.

25. Walter DE, Krantz GW. Collecting, rearing, and preparing specimens. In Krantz GW, Walter DE, editors. A manual of acarology. Texas: Tech University Press; 2009. p. 83-96

26. Murrell A, Campbell NJ, Barker SC. Phylogenetic analyses of the rhipicephaline ticks indicate that the genus Rhipicephalus is paraphyletic. Mol Phylogenet Evol. 2000;16:1-7.

27. Larkin MA, Blackshields G, Brown NP, Chenna R, McGettigan PA, McWilliam $H$, et al. Clustal W and Clustal X version 2.0. Bioinformatics. 2007;23:2947-8.

28. Filippova NA. Ixodid ticks of subfamily Amblyomminae. Fauna of Russia and neighbouring countries. St. Petersburg: Nauka Publishing House; 1997.

29. Szabó MP, Bertipaglia EC, Bechara GH. Cross reactivity between instars of the Rhipicephalus sanguineus (Latreille, 1806) tick. Ann N Y Acad Sci. 2000; 916:605-9.

30. Labruna MB, Gerardi M, Krawczak FS, Moraes-Filho J. Comparative biology of the tropical and temperate species of Rhipicephalus sanguineus sensu lato (Acari: Ixodidae) under different laboratory conditions. Ticks Tick Borne Dis. 2017;8:146-56

31. Oliver JH Jr, Wilkinson PR, Kohls GM. Observations on hybridization of three species of North American Dermacentor ticks. J Parasitol. 1972;58:380-4.

32. Davey RB, Cooksey LM, Despins JL. Survival of larvae of Boophilus annulatus, Boophilus microplus, and Boophilus hybrids (Acari: Ixodidae) in different temperature and humidity regimes in the laboratory. Vet Parasitol. 1991;40: 305-13.

33. Araya-Anchetta A, Scoles GA, Giles J, Busch JD, Wagner DM. Hybridization in natural sympatric populations of Dermacentor ticks in northwestern North America. Ecol Evol. 2013;3:714-24.

34. Zivkovic D, Pegram RG, Jongejan F, Mwase ET. Biology of Rhipicephalus appendiculatus and $R$. zambeziensis and production of a fertile hybrid under laboratory conditions. Exp Appl Acarol. 1986;2:285-98.

35. Chitimia-Dobler L, Langguth J, Pfeffer M, Kattner S, Küpper T, Friese D, et al. Genetic analysis of Rhipicephalus sanguineus sensu lato ticks parasites of dogs in Africa north of the Sahara based on mitochondrial DNA sequences. Vet Parasitol. 2017;239:1-6.

36. Gilot B, Diop S, Laforge ML. Dynamique spatio-temporelle des populations de Rhipicephalus sanguineus (Latreille, 1806) (Acariens Ixodoidea) dans una cite HLM de Marseille. Acarologia. 1992;33:127-40.

37. Lorusso V, Dantas-Torres F, Lia RP, Tarallo VD, Mencke N, Capelli G, Otranto D. Seasonal dynamics of the brown dog tick, Rhipicephalus sanguineus, on a confined dog population in Italy. Med Vet Entomol. 2010;24:309-15.

38. Rebolledo-Jaramillo B, Su MS, Stoler N, McElhoe JA, Dickins B, Blankenberg $D$, et al. Maternal age effect and severe germ-line bottleneck in the inheritance of human mitochondrial DNA. Proc Natl Acad Sci USA. 2014;111: 15474-9.

39. Nunes MD, Dolezal M, Schlötterer C. Extensive paternal mtDNA leakage in natural populations of Drosophila melanogaster. Mol Ecol. 2013;22:2106-17.

\section{Ready to submit your research? Choose BMC and benefit from:}

- fast, convenient online submission

- thorough peer review by experienced researchers in your field

- rapid publication on acceptance

- support for research data, including large and complex data types

- gold Open Access which fosters wider collaboration and increased citations

- maximum visibility for your research: over $100 \mathrm{M}$ website views per year

At BMC, research is always in progress.

Learn more biomedcentral.com/submissions 